\title{
Inna Amesheva*
}

\section{Environmental Degradation and Economic Development in China: An Interrelated Governance Challenge}

DOI 10.1515/ldr-2017-0020

\begin{abstract}
The author argues that the deterioration of the natural environment in China provides a persuasive reason to reorient China's economic growth towards a more sustainable path. Reconciling the development and environment imperatives needs to become an urgent priority for the Chinese government in order to avert the cascading implications that will arise in terms of social unrest, loss of further development opportunities as well as deepening income inequality. This paper thus examines the inter-relationship between the current ecological challenge in China and the need for economic sustainability. It evaluates the extent of environmental damage in China and focuses on the environmental impact on development and social inequality. The paper then examines the recent legislative measures that have been taken by the Chinese government to address the problem of inefficient environmental monitoring. The author suggests that further reform is needed to achieve an economically and ecologically just pathway for China's future. The paper therefore demonstrates that the environmentdevelopment challenge in China is mainly a challenge of governance. Resolving it will contribute to better environmental justice and development.
\end{abstract}

Keywords: climate change, China, sustainable development

\section{Introduction}

China's environmental degradation is unprecedented: indoor and outdoor air pollution is estimated to kill 656,000 Chinese citizens each year ${ }^{1}$; what is more,

\footnotetext{
1 Kevin Holden Platt, Chinese Air Pollution Deadliest in World, Report Says, National Geographic, 2007, available at: <http://news.nationalgeographic.com/news/2007/07/070709china-pollution.html>, accessed 26 April 2017.
}

*Corresponding author: Inna Amesheva, Law, University of Hong Kong, Hong Kong, P. R. China, E-mail: i.amesheva@gmail.com 
according to a 2014 government study, more than one-fifth of China's farmland is contaminated. ${ }^{2}$ China also suffers from high levels of desertification and soil erosion, with about $30 \%$ of China's land affected by desertification and $37 \%$ by soil erosion. ${ }^{3} 320$ million people in China lack access to safe drinking water. ${ }^{4}$ Environmental pollution, which has arisen from China's rapid industrialization, carries a high human, ${ }^{5}$ but also an extraordinary economic cost, as will be demonstrated in this paper. This has direct implications for the Chinese people's prospects for achieving the global goals of sustainable development. ${ }^{6}$ Despite China's rapid economic success during the preceding decades, there are still 157 million people in the county living below the internationally recognized poverty line of US\$ 1.25 a day. ${ }^{7}$ This paper shows that given the persevering levels of deprivation in China, the country's government is unlikely to disregard the prevailing imperative of economic growth "at all costs," unless there is another, equally compelling, reason to do so. ${ }^{8}$

The author argues that the deterioration of the natural environment in China provides one such persuasive reason. Reconciling the development and environment imperatives needs to become an urgent priority for Chinese political leadership in order to avert the cascading implications that will arise in terms of social unrest, loss of further development opportunities as

2 Xinhua Insight: China alerted by serious soil pollution, vows better protection, available at: <http://news.xinhuanet.com/english/indepth/2014-04/17/c_133270984.htm>, accessed 26 April 2017.

3 See Wing Thye Woo, The Challenges of Governance Structure, Trade Disputes and Natural Environment to China's Growth, 40 Comparative Economic Studies, no. 4 (2007), 572-602.

4400 out of China's 660 cities experience water shortages (Woo (2007) ibid., p. 16). 3/5th of China's groundwater is polluted, supra note 2. Susan Jakes, China's Water Woes, Time, 2 October 2006, available at: <http://www.time.com/time/asia/2006/environment/water.html>, accessed 26 April 2017.

5 Deaths caused by pollution are estimated by the UN to amount to 2.35 million, United Nations in China, Environment and Health in the People's Republic of China, Occasional Paper (2007), available at: <http://www.un.org.cn/public/resource/386597d44849bbc2d156a67c2a0328f2.pdf>. A 2007 Study by the OECD estimated that "China's air pollution will cause 20 million people a year to fall ill with respiratory diseases.” See "OECD highlights Chinese Pollution”, Financial Times, 17 July 2007.

6 The sustainable development goals were adopted in September 2015 by the United Nations General Assembly.

7 World Bank data, available at: <http://databank.worldbank.org/data/views/variableselection/ selectvariables.aspx? ?source $=$ poverty-and-inequality-database\# $>$. The number rises to 362 million if a poverty line of $\$ 2$ a day is taken and to 900 million people living below $\$ 5$ dollars per day. $8 \mathrm{~V}$. Li and G. Lang, China's “Green GDP” experiment and the struggle for ecological modernisation, 40 Journal of Contemporary Asia, no. 1 (2010), 44-62, 46. 
well as deepening income inequality. The paper thus examines the interrelationship between the current ecological challenges in China and the need for economic sustainability. Section 2 goes on to evaluate the extent of environmental damage in China; Section 3 focuses on the environmental impact on development and social inequality; Section 4 examines the recent legislative measures that have been taken by the Chinese government to address the problem of inadequate environmental regulations; and Section 5 suggests further reform needed to achieve an economically and ecologically sound outlook for China. The conclusion summarizes the paper's main findings, demonstrating that the environment-development challenge in China is mainly a challenge of governance. Resolving it will contribute to improved environmental justice, ${ }^{9}$ which is essential if China is to continue its path towards sustainable development.

\section{Environmental degradation in China and its unequal sway}

Despite tremendous economic growth achieved in China during the preceding decades, the impact of pollution, similar to the distribution of economic gains, is not felt equally across the Chinese population and territory - different communities bear the brunt of environmental degradation to different extents. Urban residents are mainly affected by smog and air pollution, while rural inhabitants have to also bear the impact of land and water contamination. ${ }^{10}$ In a 2011 report, China's national Environmental Protection Agency stressed the transfer of heavy pollution from urban to rural areas, acknowledging the inadequate monitoring of pollution in rural regions. ${ }^{11}$ The situation is also exacerbated by the persistence of the hukou system in China whereby certain social services (such as schooling, housing and healthcare) are restricted to the area of an individual's

9 Defined as "equity in access to environmental goods, and fairness in social processes dealing with market or government failures to provide environmental security.” Richard Balme, The Politics of Environmental Justice in China (August 11, 2011) APSA 2011 Annual Meeting Paper. 10 Zhong Hongjun, Shanghai University of Finance and Economics, available at: <http://weibo. com/1974568711/C6PgZ9QzH>. There is another level of environmental inequality in China: The north/south divide, whereby $80 \%$ of China's water resources is concentrated in Southern China. Balme (2011) supra note 9, p. 10.

11 环保部: 工业和城市污染正向农村, available at: <http://finance.sina.com.cn/nongye/nyhgij/ 20120615/112312,323,556.shtml>. 
residency registration, diminishing the possibility of geographic mobility. Reforming this system of population control could go a long way in reducing, at least partly, environmental inequalities between rural and urban residents as "it definitely draws the line of cleavage structuring the major pattern of environmental inequity in China." 12 The poorest members of the population who live in the countryside are also facing a foul paradox in that they bear the most severe consequences of environmental damage in terms of health risks, but at the same time, they are dependent upon these same polluting industries for their continued survival and income. ${ }^{13}$ Environmental damage transpires to bear a direct correlation to the rising imbalances within Chinese society ${ }^{14}$ and could hence be linked to another phenomenon: that of rising inequalities. According to Gini $^{15}$ coefficient statistics, China is the fourth most unequal country in the world. Rising social and economic inequality in China comes to show that despite the tremendous progress the country achieved in the past decades, economic growth does not necessarily trickle down to the most disadvantaged members of the population. ${ }^{16}$

With a specific focus on environmental degradation, it is difficult, if not impossible, to separate harm to the environment from harm to human health. Indeed, polls suggest that more than $80 \%$ of the Chinese population perceive environmental problems as having greater importance than economic development. ${ }^{17}$ The environment thus needs to be recognized as a public good, to which all members of society should be entitled, irrespective of

12 Balme (2011), supra note 9, p. 16. Even though the author acknowledges that abolition, by itself, does not provide a universal panacea and more is required to reverse this inequality trend.

13 Rachel Lu, China's Real Inconvenient Truth: Its Class Divide (2015) Foreign Policy, available at: <http://foreignpolicy.com/2015/03/06/chinas-real-inconvenient-truth-its-classdivide/>, accessed 26 April 2017.

14 Balme (2011), supra note 9, p. 1.

15 The World Bank describes the Gini coefficient: "Gini index measures the extent to which the distribution of income or consumption expenditure among individuals or households within an economy deviates from a perfectly equal distribution.” World Bank Indicators, available at: <http://data.worldbank.org/indicator/SI.POV.GINI >

16 Studies show that the proportion of the poorest members of society (those living under $\$ 0.50 /$ day) actually increased from 1.9 to $2.8 \%$ between 1998 and 2005. Source: Woo (2007), supra note 3, p. 11.

17 Public Opinion Research Centre Survey (in collaboration with Shanghai Jiao Tong University). Jennifer Duggan, Kunming Pollution Protest is Tip of Rising Chinese Environmental Activism, The Guardian (May 16, 2013), available at: <http://www.theguardian.com/environment/chinas-choice/2013/may/16/kunming-pollution-protest-chinese-environmental-activism>. 
their socio-economic status. ${ }^{18}$ This contention inevitably carries with it a distributional conflict as well as "a plurality of social interests, and some tradeoff between different moral values and preferences."19 This makes the environment-development conundrum a challenge of extraordinary scale that could tear at the very fabric of Chinese society.

The persistent environmental and social problems that have hit the most vulnerable members of society in China have resulted in a loss of confidence that environmental harm could be effectively contained. This has led to incidents such as protests and mass unrest. The number and size of social unrest cases have been steadily on the rise. ${ }^{20}$ Yet, social discontent transpires to be a phenomenon that has arisen from China's own economic success. ${ }^{21}$ Enjoying greater levels of financial and personal choice than ever before, the public now feels more empowered and requires greater levels of accountability from their leadership. When it comes to the danger to public health posed by environmental degradation, the rising middle class of China is no longer afraid to speak up. Economic growth, by itself, proves to be insufficient to quell the thirst of an increasingly more affluent and educated population for improvements in other aspects of society, such as better governance.

It will be hereby illustrated that the environment/social equity relationship is not necessarily linear, nor straightforward. Indeed, a truly sustainable governance requires tremendous investment in terms of capital and resources, which are often needed for other development purposes. One example is dam construction in China, which, on the one hand provides clean energy from hydropower, thus alleviating the impacts of climate change, ${ }^{22}$ but on the

18 Even though it must be acknowledged that absolute equality is practically impossible to achieve.

19 Balme (2011), supra note 9, p. 6.

20 Alex L. Wang (“China's Environmental Tipping Point”) details that "From 2001 to 2005, Chinese environmental authorities received more than 2.53 million letters and 430,000 visits by 597,000 petitioners seeking environmental redress", in Timothy B Weston and Lionel M. Jensen (eds.) China in and Beyond the Headlines, Vol. III (Rowman \& Littlefield Publishers, 2012), p. 117.

21 Woo acknowledges that the Chinese government is acutely aware of the need for social discontent to be voiced, for fear of more severe ruptures in society, referring to a popular saying: "Making a great disturbance produces a great solution. Small disturbances produce small solutions. Without a disturbance, there will be no solution" (Woo (2007), supra note 3, p. 13). The authorities thus do understand the role public opinion plays in shaping policies.

22 Hydropower's importance in diversifying the fossil-fuel-intensive energy mix of China is recognized. According to 2011 U.S. Energy Information Administration estimates: "Coal supplied the vast majority (69\%) of China's total energy consumption in 2011. Oil was the 
other hand results in other kinds of environmental degradation such as habitat loss as well as the displacement of indigenous populations. ${ }^{23}$ A further example is China's responsibility towards global climate change abatement efforts. China is one of the countries that has historically contributed little to the problem of climate change, yet it is currently the highest emitter of greenhouse gases. ${ }^{24}$ This puts it in a position many industrialized states did not have to face, namely - a trade-off between economic development and environmental viability. The following section builds upon the insights presented so far, outlining in further detail the dilemma China faces in regard to its economic and environmental challenges.

\section{The high cost of environmental degradation}

It has become clear to Chinese political elites that ecological harm is a problem that could no longer be disregarded. Indeed, the government has grown increasingly aware of the damage resulting from environmental degradation. The Chinese State Council stated in a Decision on Implementation of Scientific Development and Strengthening on Environmental Protection that:

second-largest source, accounting for $18 \%$ of the country's total energy consumption. While China has made an effort to diversify its energy supplies, hydroelectric sources $(6 \%)$, natural gas (4\%), nuclear power (nearly $1 \%$ ), and other renewables (1\%) accounted for relatively small shares of China's energy consumption", available at: <http://www.eia.gov/countries/ analysisbriefs/China/china.pdf $>$. See also Jing Cao, Richard Garbaccio, and Mun S. Ho, China's 11th Five-Year Plan and the Environment: Reducing SO2 Emissions, 3 Environmental Economic Policy, no. 2 (2009), 231-250, 232.

231.1 million people were displaced by the Three Gorges Dam (Woo (2007), supra note 3, p. 25). Balme notes that "Dams construction comes with important controversies. The projects are often located in communities which are ethnic minorities, severely impacting their habitat as well as cultural heritage. They necessitate the resettlement of populations, which are difficult processes to handle. They also have a profound impact on local ecosystems, transforming climate and severely reducing biodiversity. Finally, they create a factor of risk, particularly important in regions exposed to earthquakes.” (Balme (2011), supra note 9, p. 25). See also Kwan S. Kim, Renping Hao, and Andrew Champeau, "Growth, Environment, and Politics: The Case of China" in China and the World Economy, proceedings of the University of Washington Research Center for International Economics (2012), p. 7, noting the adverse environmental impact produced by hydroelectric dams.

24 Balme (2011), supra note 9, p. 17. 
Developed countries experienced environmental problems in stages along their 100-year industrialization process. China has seen all of these problems appear in a concentrated 20 year period ... Environmental pollution and ecosystem destruction have caused enormous economic losses, harmed the health of the masses, and affected societal stability and environmental safety. ${ }^{25}$

This realization was long overdue, but it is nevertheless a positive sign that environmental wellbeing is now on the Chinese political radar. With calls for a cleaner economic transition being made for almost a decade, in 2004 China introduced a Green Gross Domestic Product (“GDP”) accounting process, ${ }^{26}$ culminating in the 2006 Green GDP Accounting Study Report. ${ }^{27}$ The rather conservative report ${ }^{28}$ concluded that environmental damage has resulted in costs equivalent to $3.05 \%$ of China's GDP. ${ }^{29}$ Other more inclusive studies that measure the environmental impact on a broader range of activities found that environment-related GDP loss in China amounted to as much as $8-12 \%$ of economic output. ${ }^{30}$ In addition, the cost of addressing just the challenge of climate change could amount to 6.6 trillion yuan (US\$1 trillion) over a period of 5 years. ${ }^{31}$

25 Decision on Implementation of Scientific Development and Strengthening on Environmental Protection (State Council, Dec. 3, 2005), available at: <http://www.gov.cn/zwgk/2005-12/13/ content_125736.htm>. (P.R.C.). Translation by A. Wang.

26 "Green GDP denotes the level of economic productivity after taking into account the 'negative externality' of the economy.” Li and Lang (2010), supra note 8, p. 48.

27 Green GDP Accounting Study Report 2004 Issued, Issues, Xinhua, Sept. 12, 2006, Issues, XINHUA, 12 September 2006, available at: <http://news.xinhuanet.com/english/2006-09/12/ content_5080599.htm>, accessed 26 April 2017. However, some governments like Norway have deemed environmental accounting to be impractical due to impossibility to properly price and assess costs. See Li and Lang (2010), supra note 8, p. 47.

28 China's report is conservative due to the fact that it omitted the environmental impact on public health as well as agricultural productivity, among others. See Li and Lang (2010), supra note 8, p. 48.

29 Green GDP Accounting Study Report 2004 issued (supra note 27): "The preliminary results show that economic loss caused by environmental pollution reaches 511.8 billion yuan, accounting for $3.05 \%$ of national GDP in 2004 while imputed treatment cost is 287.4 billion yuan, accounting for $1.80 \%$ of that." This brings the total cost of environmental damage in 2004 to $4.85 \%$ of China's GDP. 2010 estimates for direct GDP loss are even higher, at 3.5\%. Environment and Planning Institute, China Ministry of Environmental Protection (MEP).

30 The World Bank, Clear Water, Blue Skies: China's Environment in the New Century, 23 (1997); Elizabeth C. Economy, The River Runs Black: The Environmental Challenge to China's Future (Ithaca, Cornell University Press, 2004), pp. 18-19; Losses caused by pollutions amount to $10 \%$ of China's annual GDP, See Xinhua Net, available at: <http://news.xinhuanet.com/fortune/ 2007-03/19/content_5865124.htm>(in Chinese), accessed 26 April 2017.

31 The US\$1 trillion cost of cleaning up China's cities, Eco Business (14 June 2016), available at: <http://www.eco-business.com/news/the-us1-trillion-cost-of-cleaning-up-chinascities/?utm_medium=email\&utm_campaign=April\%2015\%20newsletter\&utm_content=April\% 
This data leads to the inevitable conclusion that China's double-digit economic growth in the past decades is not in reality that remarkable since it is largely being offset by pollution-related damage. ${ }^{32}$ On par with direct GDP losses, there are indirect economic consequences arising from the transition to a more environmentally sound economy in terms of foregone revenue from polluting enterprises and higher costs associated with renewable energy. ${ }^{33}$

While acknowledging the problem is an important and necessary first step in the right direction, a much greater effort would be required to restore China's environment. This is exacerbated by the fact that Chinese energy demand continues growing, despite energy efficiency enhancements: "Cleaner as it may be, Chinese economic growth is also more massive, with an increase in energy consumption of $70 \%$ between 2000 and 2005." ${ }^{34}$ Historically, governmental and judicial response to environmental damage tends to be slow and, like in China, the "pollute first, control later" model has been followed in a number of now developed economies such as the UK, Japan and United States. ${ }^{35}$ Indeed, economic considerations have often trumped environmental ones in policymaking ${ }^{36}$ and judicial decisions. ${ }^{37}$ The case for enhanced environmental protection only seems to arise after a certain level of economic development has been attained. However, as has been pointed out above, China can no longer afford to delay action. It needs to contain the widespread ecological collapse that has

\footnotetext{
2015\%20newsletter+Version+A+CID_62da8195996a4285270638caadb8501b\&utm_source $=$ Campaign \%20Monitor\&utm_term=The\%20US1 \%20trillion\%20cost $\% 20$ of $\% 20$ cleaning\%20up $\% 20$ Chinas \%20cities>, accessed 26 April 2017.
}

32 There have been calls to introduce Green GDP as a measure of economic progress, instead of regular GDP indicators, but this has been resisted by local officials for fear of losing their regions' competitiveness: Kwan S. Kim et al. (2012), supra note 23, p. 12. Indeed, resistance from regional government has led to the eventually indefinite postponement of the Green GDP project in China: Li and Lang (2010), supra note 8, pp. 52-53.

33 In 2007 "Due to enforcement of the environmental impact assessment (EIA) law alone, 163 proposed projects worth 774.6 billion yuan (around $\$ 100$ bn.) were put on hold." Zhang Zhongxiang, China's Reds Embrace Green, Far Eastern Economic Review (2007), 170, 5; ABI/ Inform Global, 34.

34 Balme (2011), supra note 9, p. 9.

35 This is the case for industrialized as well as for developing economies. Wang (2012), supra note 20.

36 "[N]ational pressure tends to lack consistency, and government support tends to evaporate when economic interests are too severely affected by environment protection measures." Van Rooij and Wing-Hung Lo, 2010, quoted by Balme (2011), supra note 9, p. 31.

37 Madison v. Ducktown Sulphur, Copper \& Iron Co., 83 S.W. 658, 666-67 (1904) where the court deferred to the economic and tax interests of the county in allowing the highly polluting activities of mining operators. 
plagued the country in earlier decades, lest it spill over into the social and economic fabric of society. There is evidence that the Chinese Government has now understood that it is impossible to continue with a "growth at all costs" mindset and disregard the consequences that this growth brings. ${ }^{38}$ Hence, a number of legislative and administrative measures have been introduced to tackle the product of rapid economic development.

\section{Revamped environmental protection in China}

Concern for the environment has been incorporated into the Chinese Constitution since 1978. ${ }^{39}$ Moreover, in 2005, the Chinese State Council (China's supreme executive organ) introduced an environmental public interest litigation system that plays a dual role in enforcement and monitoring of environmental legislation. ${ }^{40}$ The Center for Legal Assistance to Pollution Victims ("CLAPV") was also established in 1999 to assist environmental litigants in bringing their cases to court. It has been successful in about half of the cases brought. ${ }^{41}$ Thus, there appears to be some scope for legislative oversight and enforcement of environmental-related harm. What is more, between 2000 and 2006, the number of environmental disputes brought to Environmental Protection Bureaus more than doubled. ${ }^{42}$

In respect to climate change, the Chinese government has taken measures to combat global warming, among which is the bilateral agreement with the

38 Indeed, whilst "pollution-intensive but cost-effective industrialization" has so far been effective in China, the country must alter its growth path if it is to achieve a sustainable economy in the long run. Kwan S. Kim et al. (2012), supra note 23, p. 6.

39 The Constitution states that "the country should protect the environment and natural resources, and prevent pollutions and other public hazards” XIAN FA Article 26 (1982) (P.R. C.), available at: <http://english.people.com.cn/constitution/constitution.html>. Even though the lack of constitutional judicial review (CJR) affords no avenue to enforce such provisions.

40 Decision on Implementation of Scientific Development and Strengthening of Environmental Protection (promulgated by State Council, Dec. 3, 2005) (P.R.C.).

$41 \mathrm{Xu}$ Kezhu \& Alex Wang, Spotlight on NGO Activism in China: Recent Developments at the Center for Legal Assistance to Pollution Victims (CLAPV), China Environmental Series (2006), 103.

42 The number increased from 309,800 to 687,409. Bao Zhang and Minchun Zhang, Specialized Environmental Courts in China: Status Quo, Challenges and Responses, 30 Journal of Energy \& Natural Resources Law, no. 3 (2012), 6. The author could not find information regarding the number of disputes after 2006. 
United States to commonly tackle greenhouse gas emissions (GHGs). ${ }^{43}$ Furthermore, GHG reduction targets have been set to address not only carbon dioxide, but also other potent global warming gases such as methane. ${ }^{44}$ It is thus commendable that China has adopted a broad array of laws and regulations to deal with its environmental pollution challenges. ${ }^{45}$

Given these developments, it must be admitted that China's legislative framework has gradually improved and now provides a basis for detecting and containing environmental harm ${ }^{46}$

[S]ince 1989, the National People's Congress has enacted at least twenty-four environment and natural resources related laws. More than forty State Council regulations, 500 standards, and 600 other regulatory documents have been produced concerning pollution control, natural resources conservation, and other types of environmental management. ${ }^{47}$

There are several environmental laws in China, such as the newly amended Environmental Protection Law, ${ }^{48}$ the Law on the Prevention and Control of

43 See China Joint Announcement on Climate Change and Clean Energy Cooperation, available at: <https://www.whitehouse.gov/the-press-office/2014/11/11/fact-sheet-us-china-jointannouncement-climate-change-and-clean-energy-c $>$. This joint effort was again reiterated in 2016: U.S. -China Joint Presidential Statement on Climate Change, available at: $<$ https://www.whitehouse.gov/the-press-office/2016/03/31/us-china-joint-presidential-statement-climate-change>. The two countries are considered key in successfully tackling a global challenge such as climate change, because they are currently the two largest emitters of greenhouse gases in the world.

44 See 《2014-2015 年节能减排低碳发展行动方案》 (全文), available at: 〈http://politics.people.com.cn/n/2014/0526/c1001-25065061.html>, accessed 26 April 2017.

45 Among these are The 2015 Circular Economy Promotion Plan (available at: <http://chinawaterrisk.org/notices/chinas-circular-economy-plans-for-2015/>) that deals with recycling and waste; The 2012 Cleaner Production Promotion Law (available at: <http://www.npc.gov.cn/ englishnpc/Law/2007-12/06/content_1382101.htm>) as well as China's 13th Five Year Plan (available at: <http://news.xinhuanet.com/politics/2016lh/2016-03/17/c_1118366322.htm>) setting out the country's policy roadmap until 2020.

46 See A. Wang (2012), supra note 20, pp. 202-03; Christine J. Lee, Pollute First, Control Later No More: Combating Environmental Degradation in China Through an Approach Based in Public Interest Litigation and Public Participation, 17 Pacific Rim Law and Policy Journal (2008), 795, 799-809. Even though, as will be noted below, legislative practices on paper do not always effectively translate into viable enforcement in practical terms.

47 A. Wang (2012), supra note 20, p. 198; OECD, Environmental Compliance and Enforcement in China: An Assessment of Current Practices and Ways Forward, 19-20 (2006), available at: <http://www.oecd.org/dataoecd/33/5/37867511.pdf>.

48 Promulgated by the President, Dec. 26, 1989, effective Dec. 26, 1989, art. 41 (P.R.C.). The 2014 amendment that came into force on 1 January 2015 is landmark in its effect. 
Atmospheric Pollution, ${ }^{49}$ Law on the Prevention and Control of Water Pollution ${ }^{50}$ and the Environmental Impact Assessment Law. ${ }^{51}$ China's environmental protection framework also boasts a forestry law, ${ }^{52}$ a law on marine protection ${ }^{53}$ as well as clean production ${ }^{54}$ and energy conservation laws, ${ }^{55}$ among others. It must be noted that the Wastelands Auction Policy in Ningxia (North-western China) went a long way to overcome the urban-rural as well as local-central distinction that has so far plagued policy-making in China. ${ }^{56}$ On paper, therefore Chinese environmental law seems to be on par with other well-developed legislative systems. ${ }^{57}$

Yet, despite the achievements in the legislative process that lead to ecological protection, environmental legislation in practice is often perceived as overly broad, unclear and weak in terms of enforcement potential. ${ }^{58}$ Notwithstanding the improved awareness of environmental damage and its implications, the political response to this challenge is often muted by calls for stronger economic growth as well as the fear that environmental concerns will slow growth to levels that will destabilize Chinese political leadership. ${ }^{59}$ A number of significant challenges thus remain that need to be addressed before it can be truly claimed that China has developed an effective system that

49 Law on the Prevention and Control of Atmospheric Pollution (adopted by Standing Comm. National People’s Congress, Sept. 5, 1987, revised Aug. 29, 1995) (P.R.C.).

50 Law on the Prevention and Control of Water Pollution (promulgated by the President, May 11, 1984, effective Nov. 1, 1984) (P.R.C.).

51 Environmental Impact Assessment Law (promulgated by Standing Comm. Nat'l People's Cong., Oct. 28, 2002, effective Sept. 1, 2003), available at: <http://www.sepa.gov.cn/law/law/ 200210/t20021028_84000.htm>(P.R.C.).

52 Forestry Law (promulgated by the President, Sept. 20, 1984, effective Jan. 1, 1985).

53 Marine Environmental Protection Law (promulgated by the Standing Comm. of the National People's Congress, Aug. 23, 1982, effective Mar. 1, 1983 (P.R.C.).

54 Law on the Promotion of Clean Production (adopted by the Standing Comm. of the National People's Congress, June 29, 2002, effective Jan. 1, 2003).

55 Law on Conserving Energy (promulgated by the Standing Comm. of the National People's Congress, Nov. 1, 1997, effective Jan. 1, 1998).

56 Peter Ho, The Wasteland Auction Policy in Northwest China: Solving Environmental Degradation and Rural Poverty? 30 The Journal of Peasant Studies, no. 3-4 (2003), 121-159, 150. The author stipulates that "The Wastelands Policy permits 'open auctions' in which not only farmers, but also cadres, urban entrepreneurs, and legal entities such as mass organizations and companies are allowed to participate and, more important, gain access to rural land.” Ibid. p. 125.

57 A. Wang (2012), supra note 20, p. 203. This being said, a number of newly enacted legislative provisions are examined below.

58 A. Wang (2012), supra note 20; Elizabeth C. Economy (2004), supra note 30, p. 101.

59 Li Zhiping, The Challenges of China's Discharge Permit System and Effective Solutions, 24 Temple Journal of Science, Technology \& Environmental Law (2005), 375, 379-82 380-81. 
provides operational environmental safeguards. These challenges are to a large extent interconnected and will be addressed in turn below.

\section{Remaining challenges and scope for further reform}

The environmental situation in China has been linked to one of three types of failure that could topple the Chinese leadership, namely a "power supply" failure whereby the "economy [is] unable to move forward because it hits either a natural limit or an externally-imposed limit."60 The other two types of failure represent "a hardware failure [which] refers to the breakdown of an economic mechanism and a software failure [that] refers to a flaw in governance." ${ }^{61}$ Such failures are in turn seen as the result of governmental mismanagement and inefficiency. ${ }^{62}$ It transpires that addressing these economic and governance issues is key to removing the roadblocks to a better environment in China. This paper is predominantly concerned with the so-called "software failure" stemming from a flawed governance approach, namely examining the legal challenges to improved environmental management. It is worth pointing out, however, that the other two types of failure related to the adequate functioning of China's economy are closely inter-related.

\subsection{The Chinese legal system - A long way to go}

It could be argued that at the heart of environmental mismanagement in China lie deficiencies in the country's legal and judicial systems. ${ }^{63}$ Judicial training is lacking and there is a lot to be desired in terms of procedural guarantees.

60 Woo (2007), supra note 3, p. 7.

$61 \mathrm{Ibid}$.

62 Woo (2007), supra note 3, p. 9. Water shortages, for instance, provide a clear example of a governance failure due to the heavy mismanagement of this essential resource. Inefficient pricing of water has contributed to the fact that "only 50 percent of China's industrial water is recycled compared to 80 percent in the industrialized countries, and China consumes 3,860 cubic meters of water to produce $\$ 10,000$ of GDP compared to the world average of 965 cubic meters.” Woo (2007), supra note 3, p. 26.

63 Richard J. Ferris Jr. \& Hongjun Zhang, Reaching Out to the Rule of Law: China's Continuing Efforts to Develop an Effective Environmental Law Regime, 11 William \& Mary Bill of Rights Journal (2003), 569, 594-600. 
Judicial independence needs to be strengthened as contentious cases are often interfered with by officials who have special interests in prolonging the life of polluting enterprises. ${ }^{64}$ Furthermore, the lack of an effective judicial review procedure limits the accountability and monitoring of preventable environmental harm. ${ }^{65}$ In terms of procedure, legal penalties for environmental violations have been hardly sufficient to act as a deterrence mechanism. ${ }^{66}$ In the unlikely event that a fine is actually levied, enterprises often receive the very same amount back in terms of a tax refund. ${ }^{67}$ Environmental impact assessment rules are also insufficient in scope since they allow for "make-up" post factum impact assessments, defeating the very purpose for which they are required in the first place: precisely the need for taking proactive (as opposed to ex post) measures in identifying environmental risk. ${ }^{68}$ Public interest litigation is further deficient in that the system is largely underfunded and understaffed, with very few avenues such as CLAPV for prospective litigants to resort to. ${ }^{69}$ There are also numerous obstacles to plaintiffs during the court process, because litigation carries with it costs which are substantial and often unforeseen. ${ }^{70}$

These rule of law problems might be considered to stem from the reluctance of Chinese people to resort to the judicial system at all, since, due to China's emphasis on administrative centralization, administrative remedies are often seen as stronger and more reliable than judicial ones. ${ }^{71}$ In addition, the traditional lack of a strong separation of powers system in China has resulted in an

64 Cai Dingjian, Development of the Chinese Legal System Since 1979 and its Current Crisis and Transformation, 11 Cultural Dynamics (1999), 135, 148, 153.

65 Erin Ryan, The Elaborate Paper Tiger: Environmental Enforcement and the Rule of Law in China, 24 Duke Environmental Law \& Policy Forum 183-239 (Fall 2013), 220-222, noting the role of judicial review as not only a monitoring, but also an enforcement mechanism.

66 Penalties are often capped at $\$ 25,000$, making it cheaper to pollute and pay, rather than prevent harm.

67 The inefficient enforcement of environmental standards becomes clear when we take into account that local enterprises receive about $80 \%$ of the fine back in the form of a pollution abatement subsidy. S. Sitaraman, Regulating the Belching Dragon: Rule of Law, Politics of Enforcement, and Pollution Prevention in Post-Mao Industrial China, 18 Colorado Journal of International Environmental Law and Policy, no. 2 (2007), 267-334, 312-3.

68 A. Wang (2012), supra note 20, p. 204.

69 Ibid., p. 205.

70 Notice of the Supreme People's Court on the Printing and Distribution of "Measures for Handling Lawsuit Fees for People's Courts” (promulgated by Sup. People's Ct. June 29, 1989,), Article 8, available at: <http://www.court.gov.cn/lawdata/explain/civilcation/200304010191.htm> (P.R.C.).

71 Zhang and Zhang (2012), supra note 42, p. 18. 
amalgamation between the different branches of the government, the legislature and the judiciary, leading to a highly politicized environmental protection framework. $^{72}$

This structural rule of law challenge that China faces thus seems to derive from the blurred relationship between law and policy, whereby policies are oftentimes seen as the more significant methods of governance. ${ }^{73}$ The present system results in high levels of uncertainty and compromises citizens' right to legitimate expectations. Hence, addressing problems related to the rule of law will be key in improving not only the environment, but a host of other pressing issues faced by Chinese society.

In this regard, Erin Ryan advocates slow and gradual change rather than rapturous political turmoil as a means of reform. ${ }^{74}$ However, when the Chinese Communist Party ("CCP”) is confronted with an urgent and irreversible problem such as environmental degradation, it must be capable of displaying leadership and incentive that will strike the right balance between the competing goals of environmental stewardship and economic necessity. In addition to establishing a strong rule of law where regulations are respected in practice and not only on paper, tackling China's pollution problem would also necessarily involve dealing with corruption $^{75}$ as well as the accountability of powerful state-owned corporations.

\subsection{Corruption}

China's political situation is particular in that environmental considerations often assume a secondary role due to the economic interests of special interest groups. This in turn leads to protectionism as well as an overemphasis on local authority revenues derived from the activities of polluting enterprises. All of this acts as an obstacle at the crucial implementation stage of environmental legislation ${ }^{76}$

72 Balme (2011), supra note 9, p. 31. See also The Relationship Between the People's Congresses, the State Administrative Organs, the People's Courts and People's Procuratorates, Central People's Government, P.R.C., available at: <http://www.npc.gov.cn/englishnpc/about/2007-11/ 20/content_1373255.htm>.

73 Dan Guttman, Different Operating Systems, Envtl. F., Nov./Dec. 2008, 27.

74 Erin Ryan (2013), supra note 65, p. 224. Indeed, the author argues that incremental reform rooted in enhanced accountability and transparency, which would not arouse suspicion of abrupt change, is the only viable means by which change would voluntarily be implemented by CCP. Ibid. 229.

75 Jerome Cohen, An Introduction to Law in China, 8 Vermont Journal of Environmental Law (2007), 393, 402, describing the importance of "guanxi," or connections, within the Chinese judicial and legal system and its role in undermining effective application of the rule of law. 76 Donald Clarke, The Execution of Civil Judgments in China, 141 China Quarterly (1995), 65, 71. 
When political patronage and economic interests take precedence over the faithful implementation of these laws, environmental protection suffers alongside other fundamental goals of good governance. ${ }^{77}$

Consequently, in order to confront the endemic corruption problem in China and the resulting governance challenges, President $\mathrm{Xi}$ Jinping introduced the so-called Four Comprehensives ${ }^{78}$

(i) comprehensively building a moderately prosperous society;

(ii) comprehensively deepening reform;

(iii) comprehensively governing the country according to the law; and

(iv) comprehensively be strict in governing the party.

In addition to the emphasis on the rule of law (albeit with Chinese characteristics) and sustained reform, these postulates essentially sum up some of $\mathrm{Xi}$ Jinping's greatest challenges: namely, achieving lasting economic growth, needed to lift millions that still live in poverty, while at the same time reducing reliance on export-led manufacturing in favour of a domestic consumption-led growth model. They also reflect an increasing importance placed on innovation. Corruption and legal reform are thus high on Chinese rulers' agenda, but it remains to be seen to what extent these issues will be resolved before environmental damage becomes overwhelming. ${ }^{79}$

\section{3 "The mountains are high and the emperor is far away" - Changing performance incentives for better governance}

Despite the fact that China is still a state with a strong central apparatus of governance, the role of local officials in legal enforcement has been on

77 Erin Ryan (2013), supra note 65, p. 184.

78 These build on the 6th Plenum of the CCP aiming to establish a "harmonious society" by 2020, which is characterized by:

- a democratic society under the rule of law;

- a society based on equality and justice;

- an honest and caring society;

- a stable, vigorous and orderly society; and

a society in which humans live in harmony with nature.

79 Julie Makinen, In Beijing, political pomp abounds as China kicks off "two meetings" (March 2015), LA Times, available at: <http://www.latimes.com/world/asia/la-fg-china-politics-twomeetings-20150303-story.html>, accessed 26 April 2017. 
the rise. ${ }^{80}$ China's local-central divide might indeed be among greatest obstacles that lies before reaching environmental sustainability. This is because local governors are seen as the "biggest power wielders, with the right to initiate new industries and enterprises and to control local finance, banking, commerce, and trade." ${ }^{81}$ Commentators identify this to a situation that resembles "de facto" federalism, whereby there is an implicit or explicit bargain between local and central government regarding the prerogatives and responsibilities of each. ${ }^{82}$ Undeniably, Chinese central government requires local officials' cooperation for the implementation of any policies and reforms it promulgates. The growing prominence and vested interests of local authorities, largely the result of their expanding economic clout, hence appear to be? among the major bottlenecks that impede environmental reform. ${ }^{83}$ Conflicts of interest and economic considerations act as barriers which complicate the central-local government relationship. ${ }^{84}$ For environmental goals to be achieved in practice, it transpires that local authorities' incentives need to be aligned with the imperative of environmental preservation. Yet, China's vast geography means that a centrally enforced environmental protection framework is not materially feasible, but rather needs to be complemented by strong province-level implementation.

80 G.H. Fuller notes the asymmetry of information between central/local, which results in an imbalance of power, Gregory H. Fuller, Economic Warlords: How De Facto Federalism Inhibits China's Compliance with International Trade Law and Jeopardizes Global Environmental Initiatives, 75 Tennessee Law Review (2008), 545, 551. See also Hehui Jin, Yingyi Qian \& Barry R. Weingast, Regional Decentralization and Fiscal Incentives: Federalism, Chinese Style, 89 Journal of Public. Economics (2005), 1719, 1720.

81 Chien-min Chao, “T'iao-t’iao Versus K'uai-K'uai: A Perennial Dispute Between the Central and Local Governments in Mainland China”, in Bih-jaw Lin \& James T. Myers (eds.), Forces for Change in Contemporary China (1993), pp. 158, 161, 163.

82 Yongnian Zheng, De Facto Federalism in China: Reforms and Dynamics of Central-local Relations (World Scientific, 2007). Fuller (2008), supra note 80, p. 546.

83 See Erin Ryan (2013), supra note 65, noting that "This more subtle enforcement failure takes place somewhere between the national level, where environmental laws and policies are made, and the provincial and municipal levels where they must eventually be implemented." p. 204. See also Wang Mingyuin, Issues Related to the Implementation of China's Energy Law, 8 Vermont Journal of Environmental Law. (2007), 225, 231: "with local governments becoming "quasienterprises" due to their independent economic interests, their interests often come into conflict with the central government's economic policies, including environmental protection.” 246.

84 Chris Buckley, Silver Lining in China's Smog As It Puts Focus on Emissions (The New York Times, September 1 2013). See also Srini Sitaraman (2007), supra note 67, pp. 309-10. 
Achieving local enforcement in practice is directly linked to revamping the performance and incentive models currently in place. Governance performance metrics in China have so far been over-reliant on GDP levels and economic success. This incentives structure risks placing too much emphasis on purely monetary indicators, while ignoring other equally significant goals such as health, education or environmental sustainability. ${ }^{85}$ Officials' ranking and promotions and that are principally tied to economic growth often result in complications when environmental protection targets are to be achieved. ${ }^{86}$ This means that short-term interests favouring expediency, rather than sustainability, frequently take precedent, as opposed to longer-term stability:

[c]ustomarily, during the year running up to a Central Committee meeting, local officials push for high economic growth in their regions by pursuing projects that can achieve quick, short-term results. ${ }^{87}$

It is true that performance-based promotion, where the success indicators are not solely based on GDP, ${ }^{88}$ is more difficult to measure (as it necessarily involves the inclusion of qualitative factors that go beyond simply numerical results). Yet, this is critically needed if China is to adopt a direction towards sustained progress and development.

The loss of GDP due to unsustainable environmental practices exemplified in Section 4 above suggests that China's economic house of cards is under pressure and may soon crumble under its own weight. The financial cost resulting from environmental damage could well be outweighing the GDP gains from economic growth. Thus, environmental indicators have recently been included in Chinese officials' performance metrics so as to incentivize them to take into account the impact of economic activities on the environment. ${ }^{89}$ This is particularly pertinent when approving certain infrastructure

85 Matt Perrement and Nick Young, Premier Pledges Green Performance Assessment Amidst Dust-Filled Skies, China Development Brief, Apr. 24, 2006. Wang Mingyuin (2007) noting that "[T]he predominance of GDP as a supreme indicator for political merit ... induced local governments ... to blindly pursue local GDP growth for their own self-interest, without showing concern for the social and environmental costs." Supra note 83, p. 245.

86 Zhang Zhongxiang (2007), supra note 33, p. 33.

87 Ibid, p. 34.

88 Such as education, health, innovation and other wellbeing indicators.

89 Alex L. Wang, The Search for Sustainable Legitimacy: Environmental Law and Bureaucracy in China, 37 Harvard Environmental Law Review (2013), 365, 368, illustrating 11th Five-Year Plan efforts to change officials' performance targets for improved environmental policy implementation (the author depicts the introduction of cadre assessment for environmental targets). The 11th Plan introduced expected and compulsory targets, the former of which are primarily reliant 
projects and polluting enterprises. Local officials will therefore no longer be evaluated with regard to their provinces' GDP growth performance alone. What is more, at the Chinese People's Political Consultative Conference in early March 2015, the government acknowledged that a revised annual economic growth rate of $7 \%$ (even though still high when compared to developed country growth rates) is the new norm. ${ }^{90}$

Therefore, while economic growth retains a crucial role in China's policymaking, there is a new emphasis on social and environmental indicators. This is a welcome step that will hopefully shift the focus of Chinese governors away from a "growth at all costs" model ${ }^{91}$ towards a more holistic approach of environmental, as well as economic, sustainability. To achieve these goals, enhanced public disclosure and accountability will be key. This will be examined in the following section.

\subsection{The enforcement challenge, progressive developments and further reform}

Section 4 outlined that while environmental legislation in China is becoming more comprehensive in scope, regulatory standards represent nothing more than a "paper tiger" in practice..$^{92}$ Weak environmental protection has resulted from the poor implementation of existing laws and the gaping loopholes left by a number of legislative provisions. One reason for this lack of implementation could be traced to the reliance of regional government officials on polluting enterprises for their county's tax revenues. This in turn creates a relationship of dependence on environmentally damaging industries. ${ }^{93}$ To make matters worse,

on market forces, whilst the latter require local-central government cooperation for enforcement. Jing Cao, Richard Garbaccio, and Mun S. Ho (2009), supra note 22, p. 235.

90 This echoes the goals set out in the 12th Five-Year Plan on tackling climate change and deforestation as well as shifting the economy towards consumption-led growth and emphasis on developing rural areas. Government White Paper on China's Policies and Actions for Addressing Climate Change, pt. VII (Nov. 2011).

91 For the Chinese government's over-reliance on GDP and economic metrics, see: Jason J. Czarnezki, Climate Policy \& U.S.-China Relations, 12 Vermont Journal of Environmental Law (2011), 659, 669. See also S. Sitaraman (2007), for an argument that China is only engaging in environmental stewardship because of the fear of economic growth slowdown due to pollution, supra note 67.

92 Erin Ryan (2013), supra note 65.

93 Ibid. p. 208. 
the former Chinese State Environmental Protection Agency ("SEPA") was perceived as lacking teeth to impose any enforcement actions onto violators of the country's environmental laws, leading to a low or practically non-existent deterrence effect. ${ }^{94}$ However, recent developments in Chinese environmental protection could contribute to addressing these challenges.

For instance, in March 2008, SEPA was replaced by the new Ministry of Environmental Protection ("MEP"), elevating it to a full Ministry status. MEP now has the authority to close down and confiscate the assets of polluting enterprises. ${ }^{95}$ What is more, a revised Environmental Protection Law ("EPL"), 96 which came into effect on 1 January 2015, stipulates harsher punishments for violating enterprises and includes stronger measures to hold local officials to account. ${ }^{97}$ The new fine structure means that penalties are incurred during each continuing day of violation, as opposed to imposing one-off charges, which thus encourages more prompt compliance. ${ }^{98}$ The reformed EPL also stimulates civic participation as well as bottom-up enforcement of environmental protection standards. This is done via a renewed emphasis on public interest litigation that can be initiated by certain NGOs. ${ }^{99}$

Perhaps, the most important revision of the EPL is the new role given to local officials to act as guardians of environmental sustainability. Regional

94 Zhongxiang (2007), supra note 33, p. 36. This is complemented by a low level of fines that could be imposed, making the cost of pollution acceptable.

95 Yet, the limited enforcement capacity must be noted: "The Ministry of Environmental Protection, which oversees countless sources of pollution among a nation of 1.4 billion people, was staffed by as few as 200 employees in 2007.” Erin Ryan (2013), supra note 65, p. 197.

96 Environmental Protection Law of the People's Republic of China<http://wwwChina Relations.china.org.cn/english/environment/34356.htm>.

97 The law was amended for the first time since it was passed in 1989. See Erin Ryan, The Paper Tiger Gets Teeth: Developments in Chinese Environmental Law, The Huffington Post, 30 June 2014, available at: <http://www.huffingtonpost.com/erin-ryan/chinese-environmentallaw_b_5234210.html>, accessed 26 April 2017.

98 See Chapter V, Legal Liability, Environmental Protection Law of the People's Republic of China, available at: <http://www.china.org.cn/english/environment/34356.htm>.

99 Zhang Hong, Revised green law imposes stiffer penalties (April 2014) The South China Morning Post, available at: <http://www.scmp.com/news/china/article/1496236/revised-greenlaw-imposes-stiffer-penalties>, accessed 26 April 2017. Yet, there are standing requirements of NGOs being operational for at least 5 years before they can bring a suit, limiting the scope of potential challenges. One reason behind allowing expanded PIL (Public Interest Litigation) could be seen as the desire of the government to redirect social discontent away from mass protests onto more "legitimate" channels of expressing people's grievances (Erin Ryan 2013, supra note 65). Here, we witness an instrumentalization of the rule of law for different government purposes, evoking the notion of a rule by law instead of a rule of law. 
officials can now be dismissed "if they are found to have covered up environmental wrongdoing, falsified data, illegally withheld environmental data from the public, or failed to enforce legally required closure of violators."100 Further changes in the area of environmental impact assessment postulate that joint liability for ecological harm will be imposed on the persons responsible for implementation and supervision in case their duties have been performed in a fraudulent manner. ${ }^{101}$ Thus, obligations are imposed not only on direct perpetrators but also on complicit government officials.

Moreover, a specialized environmental branch of the highest Chinese Court (the Supreme People's Court) has also been established. It will be in charge of subordinate environmental tribunals. The creation of specialized environmental courts in China could at least partly address the problems outlined above as they would consist of an expert panel of judges that are more familiar with environmental problems, better able to deal with complex evidence and more prone to reaching consistent and less biased decisions. ${ }^{102}$

However, it must be pointed out that a fragmented approach of tackling ecosystem problems is unlikely to produce sufficient improvement due to the multidisciplinary and interconnected complex nature of environmental issues. ${ }^{103}$ One solution could lie in the establishment of cross-regional jurisdiction that overcomes local protectionism and fragmented cases. ${ }^{104}$ The lack of geographic and financial proximity to the case would, expectantly, boost judicial independence and the likelihood of an environmentally friendly outcome. These revisions of China's EPL are regarded as a welcome development in Chinese environmental protection, as well as a sign of the determination with which the Chinese

100 Erin Ryan (2014), supra note 97.

101 Ibid. It must be noted, however, that a fraudulent standard of proof might be too high and thus render this development of little practical effectiveness. See Article 7, Environmental Protection Law of the People's Republic of China, available at: <http://www.china.org.cn/ english/environment/34356.htm>.

102 G. Pring and C. Pring, Specialized Environmental Courts and Tribunals: The Explosion of New Institutions to Adjudicate Environment, Climate Change, and Sustainable Development, Conference on Access to Justice, Enforcement and the Role of Courts (2010), available at: $\langle$ www.law.du.edu/documents/ect-study/Unitar-Yale-Article.pdf $>$.

103 Craig Arnold, Fourth-generation Environmental Law: Integrationist and Multimodal, 35 William \& Mary Environmental Law and Policy Review (2010), 771. What is more, it is feared that "the same problems of political patronage and fears of retribution that have undermined environmental enforcement in the general courts are also compromising the effectiveness of the new environmental courts.” Erin Ryan (2013), supra note 65, p. 220.

104 Zhang and Zhang (2012), supra note 42, p. 20. 
government aims to tackle pollution. Indeed, the government has declared a "war on pollution" in the same way as it once sought to eradicate poverty. ${ }^{105}$

Despite these progressive changes, however, some outstanding flaws remain in the Chinese environmental protection framework. This could be partly explained through the enduring prominence of the State in China's economy: "the governments being asked to punish polluters are often the same ones that own the companies doing the polluting." 106 A lot remains to be done, and regulatory changes notwithstanding, environmental problems persist.

One way that governments could resolve this dilemma involves "getting resource-pricing right to properly reflect resource scarcities and the costs of pollution and to improve [the] financial, taxation and legal system in order to encourage energy saving, environmental protection and development of renewable energies."107 The "polluter-pays" principle could be an effective tool in identifying the perpetrators of environmental harm and holding them to account. ${ }^{108}$ However, in the case of China, where the vast majority of pollution originates from state-owned enterprises ("SOEs"), this means that the state has to be able to in effect regulate itself, which is no easy task.

Another option is to improve energy efficiency by removing subsidies to highly polluting factories and power plants. However, it is not straightforward to implement such policies, since there are various unforeseen consequences whereby the costs and benefits of subsidy cuts unevenly impact different segments of the population. ${ }^{109}$ In this regard, providing effective compensation for pollution victims could be a key to resolving the environment-poverty conundrum in China. ${ }^{110}$

105 Erin Ryan (2014), supra note 97.

106 Jack Chang, quoting Benjamin van Rooij (University of California at Irvine), in Revamped Environmental Law Raises Hope for Cleanup in China (Associated Press 14 March 2015), available at: <http://www.apnewsarchive.com/2015/Revamped-environmental-law-raises-hopes-for-cleaner-air-water-in-China-clarifies-how-to-sue/id-ae734d2ed95646428c54c1f41b60625a>, accessed 26 April 2017. Yet, it must be noted that the role of SOEs in China is diminishing: "By 1985, only $20 \%$ of industrial SOEs were controlled by the central government." Gabriella Montinola, Yingyi Qian \& Barry R. Weingast, Federalism, Chinese Style: The Political Basis for Economic Success in China, 48 World Policy (1995), 50, 62, 61-62.

107 Zhongxiang (2007), supra note 33, p. 35.

108 This principle can be found in General Principles of Civil Law and the Environmental Protection Law. Article 124 of the General Principles states that: "Any person who pollutes the environment and causes damage to others in violation of state provisions for environmental protection and the prevention of pollution shall bear civil liability in accordance with the law." 109 Jing Cao, Richard Garbaccio, and Mun S. Ho (2009), supra note 22, p. 245.

110 Balme (2011), supra note 9, p. 15, noting that "thinking in terms of ecological compensation for the use of natural resources is probably a condition of fairness when assessing ethnic 
This section aimed to demonstrate that while certain improvements have been made in the area of environmental protection in China, ${ }^{111}$ clear guidelines need to be issued and implemented with regard to the impact on the most vulnerable segments of the population, particularly in terms of providing environmental compensation. The complications of political and economic challenges that arise from the growth-environment dilemma illustrate that the cost of curbing pollution in China is extraordinary. ${ }^{112}$ This challenge could only be effectively resolved if China is willing to tackle head-on the problems that plague Chinese society through people-driven, robust and responsible policies.

\section{Conclusion}

Despite claims that China is in the process of entering a new rule of law era, ${ }^{113}$ numerous weaknesses remain in the Chinese governance apparatus, particularly in the field of environmental protection. These have to be effectively addressed, and in a rapid fashion, so as to prevent further environmental collapse that can also precipitate a social and economic crisis. This paper has the objective of demonstrating the interconnected nature of environmental and economic issues, together with the need for comprehensive solutions. It illustrated that while legislative, jurisprudential and civil society developments are underway in

environmental justice in a long-term perspective.” Jing Cao, Richard Garbaccio, and Mun S. Ho also note that, overall, the beneficial impact of environmentally friendly policies outweighs the negatives (2009), supra note 22, p. 247.

111 With the 2008 revision by China's National People's Congress of the Law on the Prevention and Control of Water Pollution. Art. 7.

112 It is indeed a three-pronged human, developmental and economic cost. Kim, et.al. note that "These power plants are vital to rural township economies. If they were to close due to either excessive pollution or insufficient energy production, workers would be without pay or employment. Therefore, plant workers, plant owners, inspectors, and regional overseers alike all find it advantageous to allow excessive pollution" (Kim et al. (2012), supra note 23, p. 8). Steve Chan also notes that when Chinese citizens are faced with the "food vs freedom" debate, they prefer the guarantee of a government that provides basic social rights: Steve Chan, Human Rights in China and the United States: Competing Visions and Discrepant Performances, 24 Human Rights. Quarterly (2002), 1035, 1039-40.

113 Randall Peerenboom, China's Long March toward Rule of Law (Cambridge University Press; First Edition edition, 2002) "there is considerable direct and indirect evidence that China is in the midst of a transition toward some version of rule of law.” p. 6. 
China, there is still a lot to be desired before the environment-development dilemma can be fully resolved. The paper put forward a number of solutions to the environmental damage situation in China, such as: a more proactive regulatory framework; increased certainty and trust in the judicial system; an improved performance-based incentives structure for key government officials and members of the judiciary; achieving a balance of power between the central and local governments; as well as applying legislation in practice and not only on paper, among others. The present paper has therefore demonstrated that China requires cooperation from all sections of society if environmental quality targets are to be achieved: from top party leadership to local officials and the attendant citizen support. ${ }^{114}$ This might be the most difficult trial that the Chinese government has yet had to face, as it does not involve "easy fix" solutions and requires coordinated cross-departmental action and robust governance at all societal and political levels. Let us hope the CCP is up for the challenge.

\section{References}

Green GDP Accounting Study Report 2004 Issued, Issues, Xinhua, September 12, 2006, available at: 〈http://news.xinhuanet.com/english/2006-09/12/content_5080599.htm>

“OECD Highlights Chinese Pollution”, Financial Times, July 2007

United Nations in China, Environment and Health in the People's Republic of China, Occasional Paper (2007), available at: <http://www.un.org.cn/public/resource/

386597d44849bbc2d156a67c2a0328f2.pdf>

Government White Paper on China's Policies and Actions for Addressing Climate Change, pt. VII (November 2011)

The US\$1 trillion cost of cleaning up China's cities, Eco Business (14 June 2016), available at: <http://www.eco-business.com/news/the-us1-trillion-cost-of-cleaning-up-chinas-cities/? utm_medium = email\&utm_campaign $=$ April\%2015\%20newsletter\&utm_content=April\% 2015\%20newsletter + Version + A + CID_62da8195996a4285270638caadb8501b\&utm _ source=Campaign \%20Monitor\&utm_term=The\%20US1\%20trillion\%20cost $\% 20$ of\% 20cleaning\%20up\%20Chinas\%20cities>

The Relationship Between the People's Congresses, the State Administrative Organs, the People's Courts and People's Procuratorates, Central People's Government, P.R.C., available at: 〈http://www.npc.gov.cn/englishnpc/about/2007-11/20/content_1373255.htm〉

《2014-2015 年节能减排低碳发展行动方案》(全文), available at: 〈http://politics.people.com. $\mathrm{cn} / \mathrm{n} / 2014 / 0526 / \mathrm{c1001-25065061.html>}$

114 It must be acknowledged that environmentally unfriendly jobs in sectors such as coal mining will necessarily have to be sacrificed, but they need to be supplemented by employment in the sustainable economy. 
Arnold, C., Fourth-Generation Environmental Law: Integrationist and Multimodal, 35 William \& Mary Environmental Law and Policy Review (2010).

Balme, R., The Politics of Environmental Justice in China (August 11, 2011) APSA 2011 Annual Meeting Paper.

Buckley, C., Silver Lining in China's Smog as It Puts Focus on Emissions, The New York Times, September 2013).

Cao, J., R. Garbaccio and M.S. Ho, China's 11th Five-Year Plan and the Environment: Reducing SO2 Emissions, 3 Environmental Economic Policy, no. 2 (2009).

Chan, S., Human Rights in China and the United States: Competing Visions and Discrepant Performances, 24 Human Rights. Quarterly (2002).

Chao, C.-M., T'iao-T'iao versus K'uai-K'uai: A Perennial Dispute between the Central and Local Governments in Mainland China, in B.-J. Lin and J.T. Myers (eds.), Forces for Change in Contemporary China (Columbia, SC: University of South Carolina, 1993), pp. 158-170.

Clarke, D., The Execution of Civil Judgments in China, 141 China Quarterly (1995).

Cohen, J., An Introduction to Law in China, 8 Vermont Journal of Environmental Law (2007).

Czarnezki, J.J., Climate Policy \& U.S.-China Relations, 12 Vermont Journal of Environmental Law (2011).

Dingjian, C., Development of the Chinese Legal System since 1979 and Its Current Crisis and Transformation, 11 Cultural Dynamics (1999).

Duggan, J., Kunming Pollution Protest is Tip of Rising Chinese Environmental Activism, The Guardian (May 16, 2013), available at: <http://www.theguardian.com/environment/ chinas-choice/2013/may/16/kunming-pollution-protest-chinese-environmental-activism>

Economy, E.C., The River Runs Black: The Environmental Challenge to China's Future (Ithaca: Cornell University Press, 2004).

Ferris, R.J., Jr. and H. Zhang, Reaching Out to the Rule of Law: China's Continuing Efforts to Develop an Effective Environmental Law Regime, 11 William \& Mary Bill of Rights Journal (2003).

Fuller, G.H., Economic Warlords: How De Facto Federalism Inhibits China's Compliance with International Trade Law and Jeopardizes Global Environmental Initiatives, 75 Tennessee Law Review (2008).

Guttman, D., Different Operating Systems, Environmental Forum (November/December 2008).

Ho, P., The Wasteland Auction Policy in Northwest China: Solving Environmental Degradation and Rural Poverty?, 30 The Journal of Peasant Studies, no. 3-4 (2003).

Holden Platt, K., Chinese Air Pollution Deadliest in World, Report Says (National Geographic, 2007), available at: <http://news.nationalgeographic.com/news/2007/07/070709-china-pollution. html>

Hong, Z., Revised green law imposes stiffer penalties (April 2014) The South China Morning Post, available at: <http://www.scmp.com/news/china/article/1496236/revised-greenlaw-imposes-stiffer-penalties>

Jack, C. and B. Van Rooij, available at University of California at Irvine, in Revamped Environmental Law Raises Hope for Cleanup in China (Associated Press, 14 March 2015), available at: <https://phys.org/news/2015-03-revamped-environmental-law-cleanup-china.html〉.

Jakes, S., China's Water Woes, Time, 2 October 2006, available at: <http://www.time.com/time/ asia/2006/environment/water.html>

Jin, H., Y. Qian and B.R. Weingast, Regional Decentralization and Fiscal Incentives: Federalism, Chinese Style, 89 Journal of Public. Economics (2005). 
Kezhu, X. and A. Wang, Spotlight on NGO Activism in China: Recent Developments at the Center for Legal Assistance to Pollution Victims (CLAPV) (China Environmental Series, 8, 2006), pp. 103-104.

Kim, K.S., R. Hao and A. Champeau, Growth, Environment, and Politics: The Case of China, in China and the World Economy, proceedings of the University of Washington Research Center for International Economics (2012).

Lee, C.J., Pollute First, Control Later No More: Combating Environmental Degradation in China through an Approach Based in Public Interest Litigation and Public Participation, 17 Pacific Rim Law and Policy Journal (2008).

Li, V. and G. Lang, China's "Green GDP” Experiment and the Struggle for Ecological Modernisation, 40 Journal of Contemporary Asia, no. 1 (2010).

Lu, R., China's Real Inconvenient Truth: Its Class Divide (2015) Foreign Policy, available at: <http://foreignpolicy.com/2015/03/06/chinas-real-inconvenient-truth-its-class-divide/>

Makinen, J., In Beijing, political pomp abounds as China kicks off 'two meetings' (March 2015), LA Times, available at: <http://www.latimes.com/world/asia/la-fg-china-politics-twomeetings-20150303-story.html>

Matt, P. and N. Young, Premier Pledges Green Performance Assessment Amidst Dust-Filled Skies, China Development Brief (24 April 2006).

Mingyuin, W., Issues Related to the Implementation of China's Energy Law, 8 Vermont Journal of Environmental Law (2007).

Montinola, G., Y. Qian and B.R. Weingast, Federalism, Chinese Style: The Political Basis for Economic Success in China, 48 World Policy (1995).

OECD, Environmental Compliance and Enforcement in China: An Assessment of Current Practices and Ways Forward, 19-20 (2006), available at: <http://www.oecd.org/dataoecd/ 33/5/37867511.pdf>

Peerenboom, R., China's Long March toward Rule of Law (1st ed., Cambridge: Cambridge University Press, 2002).

Pring, G. and C. Pring, Specialized Environmental Courts and Tribunals: The Explosion of New Institutions to Adjudicate Environment, Climate Change, and Sustainable Development, Conference on Access to Justice, Enforcement and the Role of Courts (2010), available at: 〈http://www.law.du.edu/documents/ect-study/ECTs-and-Climate-Change\%20-2010.pdf>

Ryan, E., The Elaborate Paper Tiger: Environmental Enforcement and the Rule of Law in China, 24 Duke Environmental Law \& Policy Forum (Fall 2013).

Ryan, E., The Paper Tiger Gets Teeth: Developments in Chinese Environmental Law, The Huffington Post, 30 June 2014, available at: <http://www.huffingtonpost.com/erin-ryan/ chinese-environmental-law_b_5234210.html>

Sitaraman, S., Regulating the Belching Dragon: Rule of Law, Politics of Enforcement, and Pollution Prevention in Post-Mao Industrial China, 18 Colorado Journal of International Environmental Law and Policy, no. 2 (2007).

The World Bank, Clear Water, Blue Skies: China's Environment in the New Century, 23 (1997).

Wang, A.L., "China's Environmental Tipping Point”, in T.B. Weston and L.M. Jensen (eds.), China in and beyond the Headlines, Vol. III (Lanham, MD: Rowman \& Littlefield Publishers, 2012).

Wang, A.L., The Search for Sustainable Legitimacy: Environmental Law and Bureaucracy in China, 37 Harvard Environmental Law Review (2013).

Woo, W.T., The Challenges of Governance Structure, Trade Disputes and Natural Environment to China's Growth, 40 Comparative Economic Studies, no. 4 (2007). 
Zhang, B. and M. Zhang, Specialized Environmental Courts in China: Status Quo, Challenges and Responses, 30 Journal of Energy \& Natural Resources Law, no. 3 (August 2012).

Zheng, Y., De Facto Federalism in China: Reforms and Dynamics of Central-Local Relations (Singapore: World Scientific, 2007).

Zhiping, L., The Challenges of China's Discharge Permit System and Effective Solutions, 24 Temple Journal of Science, Technology \& Environmental Law (2005).

Zhongxiang, Z., China's Reds Embrace Green, 170 Far Eastern Economic Review (2007); ABI/ Inform Global, 34.

环保部: 工业和城市污染正向农村, available at: 〈http://finance.sina.com.cn/nongye/nyhgij/ 20120615/112312323556.shtml> 
Reproduced with permission of copyright owner.

Further reproduction prohibited without permission. 